\title{
Perkembangan Sejarah Antropologi Hukum dari Masa ke Masa
}

\author{
Arie Yudha Pratama \\ Email: arieyudhapratama22@gmail.com \\ No BP: 2110003600281 \\ Universitas Eka Sakti Padang
}

\section{A. PENDAHULUAN}

Antropologi Hukum merupakan salah satu mata kuliah di Fakultas Hukum. Antropologi Hukum sendiri terdiri dari dua kata yaitu Antropologi dan Hukum. Kata Antropologi secara etimologis berasal dari bahasa Yunani yaitu Anthropos yang berarti manusia dan logos berartiilmu pengetahuan. Jadi, antropologi adalah ilmu yang mempelajari tentang manusia.Sedangkan hukum merupakan suatu aturan, norma atau kaidah yang mengatur dan menjadi pedoman tingkah laku manusia. Sehingga dapat dikatakan bahwa antropologi hukum merupakan ilmu yang mempelajari mengenai peran, status atau kedudukan, nilai, norma danjuga budaya atau kebudayaan manusia. Kesemuanya ini merupakan bahan kajian dan merupakan hal yang sangat erat dalam mempelajari antropologi hukum.Sejak warsa 1980-an dunia pendidikan ilmu hukum di Indonesia semakin diperkaya dengan pengenalan studi-studi hukum empiris dengan menggunakan pendekatan antropologis. Untuk ini, T.O. Ihromi dan Valerine J.L. Kriekhoff dari UI bekerjasama dengan F. von Benda-Beckmann dari Wageningen Agriculture University the Netherlands dapat dinobatkan sebagai peletak dasar studi-studi antropologis tentang hukum yang kemudian dikenal sebagai antropologi hukum (anthropology of law, legal anthropology, anthropologicalstudy of law). Antropologi hukum pada dasarnya adalah sub disiplin ilmu hukum empiris yang memusatkan perhatiannya pada studi-studi hukum dengan menggunakan pendekatan antropologis.

Kendati demikian, dari sudut pandang antropologi, sub disiplin antropologi budaya yang memfokuskan kajiannya pada fenomena empiris kehidupan hukum dalam masyarakat secara 
luas dikenal sebagai antropologi hukum. Antropologi hukum pada dasarnya mempelajari hubungan timbal-balik antara hukum dengan fenomena-fenomena sosial secara empiris dalam kehidupan masyarakat, bagaimana hukum berfungsi dalam kehidupan masyarakat, atau bagaimana hukum bekerja sebagai alat pengendalian sosial(social control) atau sarana untuk menjaga keteraturan sosial (social order) dalam masyarakat. Dengan kata lain, studi-studi antropologis mengenai hukum memberi perhatian pada segi-segi kebudayaan manusia yang berkaitan dengan fenomena hukum dalam fungsinya sebagai sarana menjaga keteraturan sosial atau alat pengendalian sosial (Pospisil, 1971:x, 1973:538;Ihromi, 1989:8).Karena itu, studi antropologis mengenai hukum secara khusus mempelajari proses-proses sosial di mana pengaturan mengenai hak dan kewajiban warga masyarakat diciptakan, dirobah, dimanipulasi, di interpretasi, dan di implementasikan oleh warga masyarakat (F. von Benda-Beckmann, 1979, 1986). Dari penjelasan tersebut kita dapat menyimpulkan bahwa betapa pentingnya mempelajari ilmu antropologi hukum sebagai ilmu yang mempelajari tentang bagaimana norma-norma hukum itu di implementasikan di dalam kehidupan sosial masyarakat sehingga dalam makalah ini mencoba untuk memberi pemahaman mengenai bagaimana perkembangan antropologi Hukum dalam dunia pendidikan.

\section{B. PEMBAHASAN}

1. Fase awal studi teoritis mengenai hukum dengan pendekatan antropologis.

Awal pemikiran antropologis tentang hukum pada kenyataannya dimulai dengan studistudi yang dilakukan oleh kalangan ahli antropologi dan bukan dari kalangan sarjana hukum. Awal kelahiran antropologi hukum biasanya dikaitkan dengan karya klasik Sir Henry Maine yang bertajuk The Ancient Law yang diterbitkan pertama kali pada tahun 1861. Ia dipandang sebagai peletak dasar studi antropologis tentang hukum melalui introduksi teori evolusionistik (the evolusionistic theory) mengenai masyarakat dan hukum, yang secara ringkas menyatakan bahwa: hukum berkembang seiring dan sejalan dengan perkembangan masyarakat, dari masyarakat yang sederhana (primitive), tradisional, dan kesukuan (tribal) kemasyarakat yang kompleks dan modern, dan hukum yang inherent dengan masyarakat semula menekankan pada status kemudian wujudnya berkembang ke bentuk kontrak (Nader, 1965;Roberts, 1979; 
Krygier, 1980; Snyder, 1981).Tema kajian pada fase awal ini difokuskan pada fenomena hukum dalam masyarakat yang bersahaja (primitive), tradisional (traditional), dan kesukuan (tribal) dalam skala evolusi bentuk-bentuk organisasi sosial dan hukum yang mengiringi perkembangan masyarakat manusia. Sedangkan, metode kajian yang digunakan untuk memahami fenomena hukum dalam masyarakat adalah apa yang dikenal sebagai armchair methodology, yaitu metodologi untuk memahami hukum dalam perkembangan masyarakat melalui kajiankajian yang dilakukan di belakang meja, sambil duduk di kursi empuk, dalam ruangan yang nyaman,dengan membaca dan menganalisis sebanyak mungkin documentary data yang bersumber dari catatan-catatan perjalanan para petualang atau pelancong, dari laporan-laporan berkaladan dokumen resmi para missionaris, pegawai sipil maupun para serdadu pemerintah kolonial dari daerah-daerah jajahannya (F. von Benda-Beckmann, 1989).

2. Fase pada abad ke-20 Pada awal abad ke-20

metode kajian hukum seperti yang dilakukan pada fase awal mulai ditinggalkan, dan mulai memasuki perkembangan metode studi lapangan (fieldworkmethodology) dalam studistudi antropologis tentang hukum. Karya Barton, misalnya, yang berjudul Ifugao Law yang dipublikasikan pertama kali pada tahun 1919 merupakan hasil dari field work yang intensif dalam masyarakat suku Ifugao di Pulau Luzon Philipina. Kemudian,muncul karya Malinowski berjudul Crime and Custom in Savage Society yang pertama kali di publikasikan pada tahun 1926 adalah hasil studi lapangan yang komprehensif dalam masyarakat suku Trobrian di kawasan Lautan Pasific, dan seterusnya sampai sekarang metode field work menjadi metode khas dalam studi-studi antropologi hukum. Karya Barton, misalnya, yang berjudul Ifugao Law yang dipublikasikan pertama kali pada tahun 1919 merupakan hasil dari fieldwork yang intensif dalam masyarakat suku Ifugao di Pulau Luzon Philipina. Kemudian, muncul karya Malinowski berjudul Crime and Custom in Savage Society yang pertama kali dipublikasikan pada tahun 1926 adalah hasil studi lapangan yang komprehensif dalam masyarakat suku Trobrian di kawasan Lautan Pasific, dan seterusnya sampai sekarang metode fieldwork menjadi metode khas dalam studi-studi antropologi hukum. 
3. Fase (setelah tahun 1930-an)

Pada fase ini, Antropologi berkembang secara pesat. Kebudayaan-kebudayaan suku bangsa asli yang di jajah bangsa Eropa, mulai hilang akibat terpengaruh kebudayaan bangsa Eropa. Pada masa ini pula terjadi sebuah perang besar di Eropa, Perang Dunia II. Perang ini membawa banyak perubahan dalam kehidupan manusia dan membawa sebagian besar negaranegara di dunia kepada kehancuran total. Kehancuran itu menghasilkan kemiskinan, kesenjangan sosial, dan kesengsaraan yang tak berujung. Namun pada saat itu juga, muncul semangat nasionalisme bangsa-bangsa yang dijajah Eropa untuk keluar dari belenggu penjajahan. Sebagian dari bangsa-bangsa tersebut berhasil mereka. Namun banyak masyarakatnya yang masih memendam dendam terhadap bangsa Eropa yang telah menjajah mereka selama bertahun-tahun. Proses-proses perubahan tersebut menyebabkan perhatian ilmu antropologi tidak lagi ditujukan kepada penduduk pedesaan di luar Eropa, tetapi juga kepada suku bangsa di daerah pedalaman Eropa seperti suku bangsa Soami, Flam dan Lapp.

Dalam kenyataannya, Antropologi mempelajari semua mahluk manusia yang pernah hidup pada semua waktu dan semua tempat yang ada di muka bumi ini. Mahluk manusia ini hanyalah satu dari sekian banyak bentuk mahluk hidup yang ada di bumi ini yang diperkirakan muncul lebih dari 4 milyar tahun yang lalu. Antropologi bukanlah satu satunya ilmu yang mempelajari manusia. Ilmu-ilmu lain seperti ilmu Politik yang mempelajari kehidupan politik manusia, ilmu Ekonomi yang mempelajari ekonomi manusia atau ilmu Fisiologi yang mempelajari tubuh manusia dan masih banyak lagi ilmu-ilmu lain, juga mempelajari manusia. Tetapi ilmu-ilmu ini tidak mempelajari atau melihat manusia secara menyeluruh atau dalam ilmu Antropologi disebut dengan Holistik, seperti yang dilakukan oleh Antropologi.

4. Fase pada dekade tahun 1940-an sampai dengan 1950-an

Pada dekade tahun 1940-an sampai 1950-an tema-tema kajian antropologi hukum mulaibergeser ke mekanisme-mekanisme penyelesaian sengketa dalam masyarakat sederhana.Karya klasik dari Llewellyn dan Hoebel bertajuk The Cheyenne Way (1941) merupakan hasil studi lapangan kolaborasi dari seorang sarjana hukum dengan ahli 
antropologi dalam masyarakat suku Cheyenne (suku Indian) di Amerika Serikat. Kemudian, Hoebel mempublikasikan The Law of Primitive Man (1954), disusul dengan karya Gluckman mengenai hukum orang Barotse dan Lozi di Afrika, karya Bohannan mengenai hukum orangTiv, karya Gulliver mengenai hukum orang Arusha dan Ndendeuli, karya Fallers mengenai hukum dalam masyarakat suku Soga, dan karya Pospisil tentang hukum orang Kapauku di apua. Fase perkembangan tema studi antropologi hukum ke arah mekanismemekanisme peneyelesaian sengketa seperti ini disebut oleh F. von Benda-Beckmann (1989) sebagai fasethe anthropology of dispute settlements.

Namun pada saat itu juga, muncul semangat nasionalisme bangsa-bangsa yang dijajah Eropa untuk keluar dari belenggu penjajahan. Sebagian dari bangsa-bangsa tersebut berhasil mereka. Namun banyak masyarakatnya yang masih memendam dendam terhadap bangsa Eropa yang telah menjajah mereka selama bertahun-tahun. Proses-proses perubahan tersebut menyebabkan perhatian ilmu antropologi tidak lagi ditujukan kepada penduduk pedesaan di luar Eropa, tetapi juga kepada suku bangsa di daerah pedalaman Eropa seperti suku bangsa Soami, Flam dan Lapp. Dalam kenyataannya, Antropologi mempelajari semua mahluk manusia yang pernah hidup pada semua waktu dan semua tempat yang ada di muka bumi ini. Mahluk manusia ini hanyalah satu dari sekian banyak bentuk mahluk hidup yang ada di bumi ini yang diperkirakan muncul lebih dari 4 milyar tahun yang lalu.

Antropologi bukanlah satu satunya ilmu yang mempelajari manusia. Ilmu-ilmu lain seperti ilmu Politik yang mempelajari kehidupan politik manusia, ilmu Ekonomi yang mempelajari ekonomi manusia atau ilmu Fisiologi yang mempelajari tubuh manusia dan masih banyak lagi ilmuilmu lain, juga mempelajari manusia. Tetapi ilmu-ilmu ini tidak mempelajari atau melihat manusia secara menyeluruh atau dalam ilmu Antropologi disebut dengan Holistik, seperti yang dilakukan oleh Antropologi. Antropologi berusaha untuk melihat segala aspek dari diri mahluk manusia pada semua waktu dan di semua tempat, seperti: Apa yang secara umum dimiliki oleh semua manusia? Dalam hal apa saja mereka itu berbeda? Mengapa mereka bertingkah-laku seperti itu? Ini semua adalah beberapa contoh pertanyaan mendasar dalam studistudi Antropologi.

5. Fase pada dekade tahun 1960-an 
Pada dekade tahun 1960-an tema studi-studi antropologi lebih memberi perhatian pada fenomena kemajemukan hukum atau pluralisme hukum. Tema pluralisme hukum pertama-tama difokuskan pada kemajemukan cara-cara penyelesaian melalui mekanisme tradisional, tetapi kemudian diarahkan kepada mekanisme dan institusi penyelesaian sengketa menurut hukum pemerintah kolonial dan pemerintah negara-negara yang sudah merdeka. Karya Bohannan, Gluckman, dan Gulliver misalnya, tidak secara sistematis memberi perhatian pada eksistensi mekanisme dan institusi penyelesaian sengketa menurut hukum kolonial dan hukum negaranegara sedang berkembang.

\section{Fase pada dekade 1970-an}

Sejak tahun 1970-an tema studi-studi antropologi hukum secara sistematis difokuskan pada hubungan antar institusi-institusi penyelesaian sengketa secara tradisional, neo-tradisional, dan menurut institusi hukum negara. Karya Nader dan Todd (1978) misalnya, memfokuskan kajiannya pada proses, mekanisme, dan institusi-institusi penyelesaian sengketa di komunitas masyarakat tradisional dan modern di beberapa negara di dunia, melalui Berkeley Village Law Projects, menjadi karya yang memperlihatkan kecenderungan baru dari topik-topik studi antropologi hukum. Publikasi lain yang perlu dicatat adalah mekanisme penyelesaian sengketa di kalangan orang Togo di Afrika karya van Rouveroy van Nieuwaal, kemudian karya F. von Benda-Beckmann (1979) dan K. von Benda-Beckmann (1984) yang memberi pemahaman tentang penyelesaian sengketa harta warisan di kalangan orang Minangkabau menurut pengadilan adat dan di pengadilan negeri di Sumatera Barat. Fase selanjutnya studi pluralisme mekanisme penyelesaian sengketa mulai ditinggalkan, dan mulai diarahkan kepada studi-studi pluralisme hukum di luar penyelesaian sengketa. Karya Sally F. Moore (1978) misalnya, mengenai kemajemukan hukum agraris dalam kehidupan suku Kilimanjaro di Afrika, dan mekanisme dalam proses produksi pabrik garment terkenal di Amerika dapat dicatat sebagai perkembangan baru studi pluralisme hukum. Kemudian, studi-studi pluralisme hukum mulai difokuskan pada mekanisme jaminan sosial (social security), pasar dan perdagangan, mekanisme irigasi pertanian, institusi koperasi dan perkreditan di daerah pedesaan di negara-negara sedang berkembang. Studi-studi ini dikembangkan oleh Agrarian Law Department Wageningen Agriculture University. Fase perkembangan tema pluralisme hukum yang menyoroti topik-topik 
penyelesaian sengketa maupun non penyelesaian sengketa, interaksi antara hukum negara, hukum rakyat, atau dengan hukum agama disebut oleh F. von Benda-Beckmann (1989) sebagai fase the anthropology of legal pluralism. Kecenderungan yang berkembang sejak tahun 1970-an adalah penggunaan pendekatan sejarah dalam studi-studi antropologi hukum. Studi yang dilakukan Moore (1986), Snyder (1981), F. von Benda-Beckmann (1979), K. von BendaBeckmann (1984) misalnya, secara eksplisit menggunakan kombinasi dimensi sejarah untuk menjelaskan interaksi institusi hukum negara (state law) dengan hukum rakyat (folk law) dalam kajian pluralisme hukum penyelesaian sengketa.

\section{B. PENUTUP}

Antropologi adalah salah satu cabang ilmu pengetahuan sosial yang mempelajari tentang budaya masyarakat suatu etnis tertentu. Perkembangan antropologi terdiri atas 4 tahap yaitu ;

1) Fase Pertama (Sebelum tahun 1800-an)

Awal pemikiran antropologis tentang hukum pada kenyataannya dimulai dengan studi-studi yang dilakukan oleh kalangan ahli antropologi dan bukan dari kalangan sarjana hukum.

2) Fase Kedua (tahun 1800-an)

Mereka menganggap bangsa-bangsa selain Eropa sebagai bangsa-bangsa primitif yang tertinggal, dan menganggap Eropa sebagai bangsa yang tinggi kebudayaannya.

3) Fase Ketiga (awal abad ke-20)

Dalam rangka membangun koloni-koloni tersebut, muncul berbagai kendala seperti serangan dari bangsa asli, pemberontakan-pemberontakan, cuaca yang kurang cocok bagi bangsa Eropa serta hambatan-hambatan lain.

4) Fase Keempat (setelah tahun 1930-an)

Pada fase ini, Antropologi berkembang secara pesat. Kebudayaan-kebudayaan suku bangsa asli yang dijajah bangsa Eropa, mulai hilang akibat terpengaruh kebudayaan bangsa Eropa.

5) Fase Pada dekade tahun 1960-an tema studi-studi antropologi lebih memberi perhatian pada fenomena kemajemukan hukum atau pluralisme hukum.

6) Fase pada dekade 1970-an

Sejak tahun 1970-an tema studi-studi antropologi hukum secara sistematis difokuskan pada 
hubungan antar institusi-institusi penyelesaian sengketa secara tradisional, neo-tradisional, dan menurut institusi hukum negara.

\section{DAFTAR PUSTAKA}

Darmini Roza dan Laurensius Arliman S, Peran Pemerintah Daerah Di Dalam Melindungi Hak Anak Di Indonesia, Masalah-Masalah Hukum, Volume 47, Nomor 1, 2018. https://doi.org/10.14710/mmh.47.1.2018.10-21

Laurensius Arliman S, Peranan Metodologi Penelitian Hukum di Dalam Perkembangan Ilmu Hukum di Indonesia, Soumatera Law Review, Volume 1, Nomor 1, 201. http://doi.org/10.22216/soumlaw.v1i1.3346.

Laurensius Arliman S, Peran Badan Permusyawaratan Desa di Dalam Pembangunan Desa dan Pengawasan Keuangan Desa, Padjadjaran Journal of Law, Volume 4, Nomor 3, 2017. https://doi.org/10.15408/jch.v4i2.3433.

Laurensius Arliman S, Penanaman Modal Asing Di Sumatera Barat Berdasarkan UndangUndang Nomor 25 Tahun 2007 Tentang Penanaman Modal, Supremasi Hukum, Volume 1, Nomor 1, 2018. http://dx.doi.org/10.36441/hukum.v1i01.102 .

Laurensius Arliman S, Memperkuat Kearifan Lokal Untuk Menangkal Intoleransi Umat Beragama Di Indonesia, Ensiklopedia of Journal, Volume 1, Nomor 1, 2018, https://doi.org/10.33559/eoj.v1i1.18.

Laurensius Arliman S, Perkawinan Antar Negara Di Indonesia Berdasarkan Hukum Perdata Internasional, Kertha Patrika, Volume 39, Nomor 3, 2017 , https://doi.org/10.24843/KP.2017.v39.i03.p03.

Laurensius Arliman S, Partisipasi Masyarakat Di Dalam Pengelolaan Uang Desa PascaUndangUndang Nomor 6 Tahun 2014 Tentang Desa, Jurnal Arena Hukum, Volume 12, Nomor 2, 2019, https://doi.org/10.21776/ub.arenahukum.2019.01202.5.

Laurensius Arliman S, Mewujudkan Penegakan Hukum Yang Baik Di Negara Hukum Indonesia, Dialogica Jurnalica, Volume 11, Nomor 1, 2019, https://doi.org/10.28932/di.v11i1.1831. 
Laurensius Arliman S, Mediasi Melalui Pendekatan Mufakat Sebagai Lembaga Alternatif Penyelesaian Sengketa Untuk Mendukung Pembangunan Ekonomi Nasional, UIR Law Review, Volume 2, Nomor 2, 2018, https://doi.org/10.25299/uirlrev.2018.vol2(02).1587

Laurensius Arliman S, Peranan Filsafat Hukum Dalam Perlindungan Hak Anak Yang Berkelanjutan Sebagai Bagian Dari Hak Asasi Manusia, Doctrinal, Volume 1, Nomor 2,2016.

Laurensius Arliman S, Ni Putu Eka Dewi, Protection of Children and Women's Rights in Indonesiathrough International Regulation Ratification, Journal of Innovation, Creativity and Change Volume 15, Nomor 6, 2021.

Laurensius Arliman S, Gagalnya Perlindungan Anak Sebagai Salah Satu Bagian Dari Hak Asasi Manusia Oleh Orang Tua Ditinjau Dari Mazhab Utilitarianisme, Jurnal Yuridis, Volume 3, Nomor 2, 2016, http://dx.doi.org/10.35586/.v3i2.180.

Laurensius Arliman S, Tantangan Pendidikan Kewarganegaraan Pada Revolusi 4.0, Jurnal Ensiklopedia Sosial Review, Volume 2, Nomor 3, $2020 .$. 